\title{
DOCUMENTATION OF MODEL INPUT AND OUTPUT VALUES FOR THE GROUND-WATER RESOURCES OF HONEY LAKE VALLEY, LASSEN COUNTY, CALIFORNIA, AND WASHOE COUNTY, NEVADA
}

By Hugh T. Mitten and Clark J. Londquist

Supplement to Water-Resources Investigations Report 90-4050

U.S. GEOLOGICAL SURVEY

Open-File Report 91-68

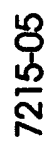




\section{U.S. DEPARTMENT OF THE INTERIOR MANUEL LUJAN, JR, Secrefary}

\section{U.S. GEOLOGICAL SURVEY \\ Dallas L. Peck, Director}

The use of brand, firm, or trade names and the use and distribution of specific products in this report are for identification purposes only, and do not imply endorsement by the U.S. Geological Survey. No warranty is made for use of the products.

For sale by the Books and Open-File Reports Section, U.S. Geological Survey Federal Center, Box 25425 Denver, CO 80225

For additional information write to:

District Chief U.S. Geological Survey Federal Building, Room W-2234 2800 Cottage Way Sacramento, CA 95825 


\title{
CONTENTS
}

\author{
Abstract 1 \\ Introduction 1 \\ Model grid 1 \\ Input and output files 1 \\ References cited 4
}

\section{TABLES}

1. Model-input files, Fortran units, maximum record length, size, and descriptions 2

2. Model-output files assigned to Fortran unit 6 , size, and descriptions 3 


\title{
DOCUMENTATION OF MODEL INPUT AND OUTPUT VALUES FOR THE GROUND-WATER RESOURCES OF HONEY LAKE VALLEY,
} LASSEN COUNTY, CALIFORNIA, AND WASHOE COUNTY, NEVADA

\author{
By Hugh T. Mitten and Clark J. Londquist
}

\begin{abstract}
Documentation of model input and sample output values for the ground-water flow system of the eastern part of the Honey Lake Valley, Lassen County, California, and Washoe County, Nevada, has not been published previously. In this report, the documentation is contained on a 5 1/4-inch diskette in files presented according to the American International Standard Code for Information Interchange. These files require approximately $1.05 \mathrm{mega}-$ bytes of disk space on an IBM-compatible microcomputer using the MS-DOS operating system.
\end{abstract}

\section{INTRODUCTION}

For a study of the ground-water resources of Honey Lake Valley, Lassen County, Califomia, and Washoe County, Nevada, a four-layer digital model was developed for the eastem part of the basin, using the computational algorithm of McDonald and Harbaugh (1988). Results of the Honey Lake Valley study are given by Handman and others (1990).

Although the report by Handman and others (1990) summarizes the data input to the model, detailed documentation of grid location, model input, and sample output has not been published previously. The purpose of this report, which is a supplement to the report by Handman and others (1990), is to provide detailed, electronic documentation of the model.

\section{MODEL GRID}

Organization of the model grid was based on a composite of U.S. Geological Survey topographic maps. The model-grid lines are oriented north-south, parallel to the northem part of the Califomia-Nevada State boundary (Handman and others, 1990). The left edge of column 13 is about 1,000 feet east of the State boundary which is 120 degrees west longitude; the bottom edge of row 17 is about 2,200 feet south of the line at 40 degrees 15 minutes north latitude.

\section{INPUT AND OUTPUT FILES}

The original input and output for the Honey Lake model were developed on a Prime computer and transferred to an IBM-compatible microcomputer (operating under MS-DOS version 3.3). Files on the diskette are the same as the original Prime computer files and are presented according to the American International Standard Code for Information Interchange (ASCII).

Although the model program runs on a variety of computers, the input data might have to be reorganized depending on the specific computer and compiler being used. There is no way to anticipate the type of system which may be used to run the Honey Lake model or which compiler will be used for the model program, which is written in Fortran 77.

The model simulated three pumping conditions: predevelopment, current (1988), and proposed. Input files for BASXXX and WLSTXXX packages (table 1) and output files (table 2) are listed for each of the three pumping conditions.

Files for the Honey Lake model are on a highdensity, double-sided, soft-sectored diskette with a 
Table 1. Model-input files, Fortran units, maximum record length, size, and descriptions

[IBOUND is a variable showing status of model cell; VCONT is a variable expressing both vertical hydraulic conductivity and vertical grid spacing. Note that the well package is used to simulate pumpage, recharge from streams, and irrigation return]

\begin{tabular}{|c|c|c|c|c|}
\hline File & Fortran unit & $\begin{array}{l}\text { Maximum } \\
\text { record length }\end{array}$ & $\begin{array}{c}\text { Size } \\
\text { (bytes) }\end{array}$ & Description \\
\hline BAS1988.PAC & 5 & $\left({ }^{1}\right)$ & 848 & Basic package using well package WLSTIRRC.PAC \\
\hline BASPRE.PAC & 5 & $\left({ }^{1}\right)$ & 848 & Basic package using well package WLSTRC.PAC \\
\hline BASPROP.PAC & 5 & $\left({ }^{1}\right)$ & 848 & Basic package using well package WLST.PAC \\
\hline BCF.PAC & 10 & $\left({ }^{1}\right)$ & 1099 & Block-centered-flow package \\
\hline BOTTOM1.DAT & 105 & 120 & 6244 & Bottom altitude, layer 1 (shallowest layer) \\
\hline BOTTOM2.DAT & 106 & 120 & 5914 & Bottom altitude, layer 2 \\
\hline BOTTOM3.DAT & 107 & 120 & 5684 & Bottom altitude, layer 3 \\
\hline BOTTOM4.DAT & 108 & 120 & 4924 & Bottom altitude, layer 4 (deepest layer) \\
\hline ETEXDP.DAT & 53 & 120 & 8784 & Evapotranspiration extinction depth \\
\hline ET.PAC & 50 & (1) & 228 & Evapotranspiration package \\
\hline ETSURF.DAT & 51 & 120 & 6364 & Evapotranspiration surface altitude \\
\hline GHB.PAC & 70 & (1) & 3986 & General-head-boundary package \\
\hline HEAD1.DAT & 35 & 125 & 7416 & Starting heads, layer 1 (shallowest layer) \\
\hline HEAD2.DAT & 36 & 125 & 7416 & Starting heads, layer 2 \\
\hline HEAD3.DAT & 37 & 125 & 7416 & Starting heads, layer 3 \\
\hline HEAD4.DAT & 38 & 125 & 7416 & Starting heads, layer 4 (deepest layer) \\
\hline HYCON1.DAT & 101 & 120 & 8784 & Hydraulic conductivity, layer 1 \\
\hline HYCON2.DAT & 102 & 120 & 8784 & Hydraulic conductivity, layer 2 \\
\hline HYCON3.DAT & 103 & 120 & 8784 & Hydraulic conductivity, layer 3 \\
\hline HYCON4.DAT & 104 & 120 & 8784 & Hydraulic conductivity, layer 4 \\
\hline IBOUNDI.DAT & 31 & $(1)$ & 2118 & Boundary, layer 1 \\
\hline IBOUND2.DAT & 32 & $\left({ }^{1}\right)$ & 1947 & Boundary, layer 2 \\
\hline IBOUND3.DAT & 33 & $\left({ }^{1}\right)$ & 1878 & Boundary, layer 3 \\
\hline IBOUND4.DAT & 34 & $\left({ }^{1}\right)$ & 1725 & Boundary, layer 4 \\
\hline OUTCON.PAC & 120 & $(1)$ & 378 & Output control package \\
\hline
\end{tabular}


Table 1. Model-input files, Fortran units, maximum record length, size, and descriptions-Continued

\begin{tabular}{|c|c|c|c|c|}
\hline File & Fortran unit & $\begin{array}{l}\text { Maximum } \\
\text { record length }\end{array}$ & $\begin{array}{c}\text { Size } \\
\text { (bytes) }\end{array}$ & Description \\
\hline RECH.DAT & 81 & 96 & 2800 & Recharge data (areal recharge) \\
\hline RECH.PAC & 80 & $\left({ }^{1}\right)$ & 86 & $\begin{array}{l}\text { Recharge package (areal recharge), in acre-feet per } \\
\text { year, converted in package to cubic feet per day }\end{array}$ \\
\hline SIP.PAC & 90 & $\left({ }^{1}\right)$ & 148 & Strongly implicit procedure package \\
\hline TOP2.DAT & 112 & 120 & 6244 & Altitude, top of layer 2 \\
\hline TOP3.DAT & 113 & 120 & 5914 & Altitude, top of layer 3 \\
\hline TOP4.DAT & 114 & 120 & 5684 & Altitude, top of layer 4 \\
\hline VCONT1.DAT & 109 & 120 & 8652 & VCONT, layer 1 \\
\hline VCONT2.DAT & 110 & 120 & 8644 & VCONT, layer 2 \\
\hline VCONT3.DAT & 111 & 120 & 8620 & VCONT, layer 3 \\
\hline WLST.PAC & 22 & $\left({ }^{1}\right)$ & 5158 & $\begin{array}{l}\text { Well package used with basic package } \\
\text { BASPROP.PAC to represent recharge from streams } \\
\text { and discharge from existing and proposed wells }\end{array}$ \\
\hline WLSTIRRC.PAC & 20 & $\left({ }^{1}\right)$ & 4440 & $\begin{array}{l}\text { Well package used with basic package BAS1988.PAC } \\
\text { to represent recharge from streams and irrigation } \\
\text { return and discharge from existing wells }\end{array}$ \\
\hline WLSTRC.PAC & 21 & $\left({ }^{1}\right)$ & 3652 & $\begin{array}{l}\text { Well package used with basic package BASPRE.PAC } \\
\text { to represent recharge from streams only }\end{array}$ \\
\hline TOTAL & & & 178659 & \\
\hline
\end{tabular}

${ }^{1}$ Record length is 80 characters or less

Table 2. Model-output files assigned to Fortran unit 6, size, and descriptions

\begin{tabular}{lcl}
\multicolumn{1}{c}{ File } & $\begin{array}{c}\text { Size } \\
\text { (bytes) }\end{array}$ & \multicolumn{1}{c}{ Description } \\
\hline SSCAL.OUT & 281109 & $\begin{array}{l}\text { Output for steady-state simulation with pumpage from existing production wells } \\
\text { calibrated to potentiometric heads during spring 1988, using BAS1988.PAC and } \\
\text { WLSTIRRC.PAC (table 1) }\end{array}$ \\
SSNOPMP.OUT & 279725 & $\begin{array}{l}\text { Output for steady-state simulation with no pumpage from production wells } \\
\text { (predevelopment conditions), using BASPRE.PAC and WLSTRC.PAC (table 1) }\end{array}$ \\
SSPMP.OUT & 283225 & $\begin{array}{l}\text { Output for steady-state simulation with proposed pumpage, using BASPROP.PAC } \\
\text { and WLST.PAC (table 1) }\end{array}$ \\
\cline { 2 - 3 } & 844059 & \\
\hline
\end{tabular}


capacity of 1.2 megabytes. The root directory on the diskette contains one file (README.DOC, which is a copy of the text of this report) and two subdirectories (INPUT and OUTPUT). Tables 1 and 2 show the contents of the subdirectories INPUT and OUTPUT and descriptions of the files. Data contained in the files are in units of feet and days, except as noted. Each record on the output file contains 132 or fewer characters. Record lengths of the input files are shown in table 1.

\section{REFERENCES CITED}

Handman, E.H., Londquist, C.J., and Maurer, D.K., 1990, Ground-water resources of Honey Lake Valley, Lassen County, California, and Washoe County, Nevada: U.S. Geological Survey Water-Resources Investigations Report 90-4050, 112 p.

McDonald, M.G., and Harbaugh, A.W., 1988, A modular three-dimensional finite-difference ground-water flow model: U.S. Geological Survey Techniques of WaterResources Investigations, Book 6, Chapter A1, 586 p. 